\title{
Microtextural characterisation of the Lower Zone in the western limb of the Bushveld Complex, South Africa: evidence for extensive melt migration within a sill complex
}

\author{
Bartosz T. Karykowski ${ }^{1}$. Wolfgang D. Maier ${ }^{1}$
}

Received: 8 March 2017 / Accepted: 2 June 2017 / Published online: 7 July 2017

(C) The Author(s) 2017. This article is an open access publication

\begin{abstract}
The Lower Zone of the Bushveld Complex comprises an up to 2-km-thick package of different ultramafic rock types with an approx. 90-cm-thick, sulphide-bearing noritic interval that occurs in the western and eastern limbs. The distribution and geometry of the zone are highly variable across the Complex, showing pronounced, yet laterally discontinuous layering on different scales. Together with the ubiquitous lack of large-scale fractionation in the $\mathrm{Mg} \#$ of orthopyroxene, variable $\mathrm{Sr}$ isotope compositions and erratic $\mathrm{Pt} / \mathrm{Pd}$ ratios, these observations strongly suggest an emplacement of the Lower Zone as a sill complex, as these contrasting geochemical characteristics are difficult to account for in a large Bushveld magma chamber, as previously suggested. It is more likely that these sills were episodically fed from a sub-Bushveld staging chamber, and variably contaminated, while passing through the crust before their final emplacement in the Lower Zone. Detailed mineralogical and microtextural work based on high-resolution elemental mapping of a set of samples, covering the entire Lower Zone stratigraphy of the western Bushveld shows that the variations in the late crystallising interstitial mineral mode are different from what would be expect, if all phases crystallised from a fixed initial mass of interstitial liquid. The interstitial mineral mode, represented
\end{abstract}

Communicated by Timothy L. Grove.

Electronic supplementary material The online version of this article (doi:10.1007/s00410-017-1380-y) contains supplementary material, which is available to authorized users.

Bartosz T. Karykowski

KarykowskiBT@ cardiff.ac.uk

1 School of Earth and Ocean Sciences, Cardiff University, Main Building, Park Place, Cardiff CF10 3AT, UK by plagioclase, clinopyroxene and other late stage phases, shows variable ratios of these minerals ranging from ca. 21:15:64 to $75: 17: 8$. In comparison to modelled expected ratios, most of the analysed rocks have higher amounts of early crystallising interstitial phases (e.g. plagioclase, clinopyroxene), relative to late crystallising phases (e.g. quartz, alkali feldspar). Therefore, interstitial melt must have migrated at different stages of fractionation during cumulate solidification, as a consequence of either compaction or displacement by convecting interstitial liquids. Two samples, however, show the opposite: late phases are relatively more abundant than early ones, which is consistent with a convection-driven replacement of primitive interstitial liquid by more evolved liquid. These results have important implications for the interpretation of the Lower Zone and, by extension, for layered intrusions in general: (1) interstitial sulphide mineralisation may be introduced into a cumulate through infiltrating melts, i.e. the liquid components of a sulphur-saturated crystal mush are not withheld from further migration, upon interaction with a cumulate pile; (2) most importantly, late stage minerals, such as zircon, rarely crystallise from trapped liquid that was initially in equilibrium with the cumulate. Therefore, dating of interstitial zircon from cumulates is unlikely to record the actual timing of emplacement, but merely the crystallisation of a later episode of residual melt that migrated through the cumulate.

Keywords Layered intrusions $\cdot$ Bushveld Complex $\cdot$ Melt migration · Lower Zone

\section{Introduction}

The Bushveld Complex of South Africa, forming the world's largest layered intrusion, hosts the most important 
platinum-group element (PGE), chromite and vanadiferous magnetite repository on Earth. The spectacular metal endowment of the Critical Zone led to a range of detailed studies focusing on this part of the intrusion, whereas the Lower Zone has traditionally received little scientific attention, in part due to the lack of economic PGE mineralisation and limited exposure. The up to 2-km-thick ultramafic unit is characterised by intricate discontinuous layering on all scales, comprising chromite-poor pyroxenite and olivine-bearing rocks with interstitial plagioclase, clinopyroxene and minor phlogopite, amphibole, quartz and sulphide (Cameron 1978a; Teigler and Eales 1996; Yudovskaya et al. 2013; Fig. 2 of present study). These interstitial phases are commonly interpreted to have crystallised as oikocrysts from trapped melt, which was in equilibrium with the surrounding cumulus crystals (e.g. Barnes 1986). However, several studies have demonstrated the significance of residual melt migration in cumulates (Irvine 1980; Tait and Jaupart 1992; Bédard et al. 1992; Meurer and Meurer 2006), whereby an interstitial melt is expelled from a framework of cumulus phases or a "crystal mush". For example, Boorman et al. (2004) suggested a compaction-driven melt migration model to explain the modest increase in plagioclase abundance, associated with the transition from the Lower Zone to the Critical Zone of the Bushveld Complex.

This process may play a critical role when it comes to the origin of interstitial sulphide mineralisation, potential isotope disequilibrium between cumulus and intercumulus minerals and more importantly geochronology (e.g. Eales et al. 1990; Prevec et al. 2005; Chutas et al. 2012; Yang et al. 2013). Modern high-precision dating of layered intrusions relies on the availability of zircon in cumulates. However, experimental studies show that zircon does not crystallise until the very late stages of fractionation (see Scoates and Wall 2015 for a detailed review). Therefore, melt migration has the potential to obscure crystallisation ages of cumulates, especially due to the fact that slow cooling of cumulate frameworks in layered intrusions facilitates enhanced porosity and permeability (e.g. Jerram et al. 2003). Moreover, the origin and nature of the conspicuous interlayering in the Lower Zone remain under debate. Models range from gravity-controlled crystal settling and density sorting of minerals in crystal slurries on top of the cumulate pile, to repeated intrusions of sills to form a sill complex (see Naslund and McBirney 1996 for a detailed review of formation models).

In this study, we present detailed information on rock textures and mineralogy based on high-resolution X-ray elemental mapping of thin sections covering the entire stratigraphy of the Lower Zone. These element maps provide an excellent resource for a detailed two-dimensional visualisation of mineralogical and chemical variations as well as microtextures across a given sample, which can help elucidate physicochemical processes active during the formation of a cumulate body, i.e. melt migration recorded by interstitial material.

\section{Geological setting}

The Bushveld Complex is composed of four different rock suites: (1) felsic volcanic rocks of the Rooiberg Group, (2) granites and granophyres of the Rashoop Granophyre Suite, (3) granitic rocks of the Lebowa Granite Suite and (4) layered mafic-ultramafic rocks of the Rustenburg Layered Suite (RLS) as the most voluminous group (Eales and Cawthorn 1996). The latter is exposed in five different areas, known as limbs, covering $>100,000 \mathrm{~km}^{2}$ of South Africa (Fig. 1). The igneous succession reaches up to $8 \mathrm{~km}$ in the eastern part of the complex, whereas the western part is slightly thinner. The immediate underlying floor rocks consist of Late Archean to Early Proterozoic chemical and siliciclastic sedimentary rocks of the Transvaal Supergroup, which were intruded by the RLS over a relatively short period of time ( $<1$ million years) between ca. 2057 and 2056 Ma (Scoates and Wall 2015; Zeh et al. 2015).

A fivefold zonal subdivision of the RLS has been traditionally used in the Bushveld Complex following Hall's (1932) seminal work. He recognised a noritic Marginal Zone at the bottom, followed by the ultramafic Lower Zone (LZ), the mafic-ultramafic Critical Zone (CZ), the gabbronoritic Main Zone (MZ) and the ferrogabbroic Upper Zone (UZ) at the top.

The origin of the Complex remains a much-debated issue, but detailed studies on fine-grained sills aiming to constrain the parental magma composition of the Bushveld resulted in the definition of three major suites of magmas after Sharpe (1981): (1) Bushveld 1 (B1) magma underlying the LZ, (2) B2 magma underlying the Upper CZ and (3) B3 magma underlying the MZ. More recent studies by Wilson (2012) and Maier et al. (2016a) concluded that the most likely parental magma to the LZ would have been a komatiitic one with $18-19 \mathrm{wt} \% \mathrm{MgO}$ derived from the asthenosphere, which assimilated some continental crust.

\section{Geology of the Lower Zone}

The LZ shows a greater variability in thickness and lateral continuity relative to all other zones. The distribution of the LZ is mainly controlled by the floor rock topography, as it generally occurs in local floor rock depressions or troughs, such as in the famous Olifants River Trough in the eastern limb of the Bushveld Complex (Cameron 1978a). The succession becomes thinner in the areas between these troughs, locally forming separated bodies (Scoon and Teigler 1995; Wilson 2015). In the far-western limb, the LZ reaches a thickness of ca. $1000 \mathrm{~m}$, thinning towards the east, where it 
Fig. 1 Simplified geological map of the Bushveld Complex showing the distribution of the Lower Zone. Samples for this study were taken from the Union Section. Modified after Yudovskaya et al. (2013). TML Thabazimbi-Murchison Lineament

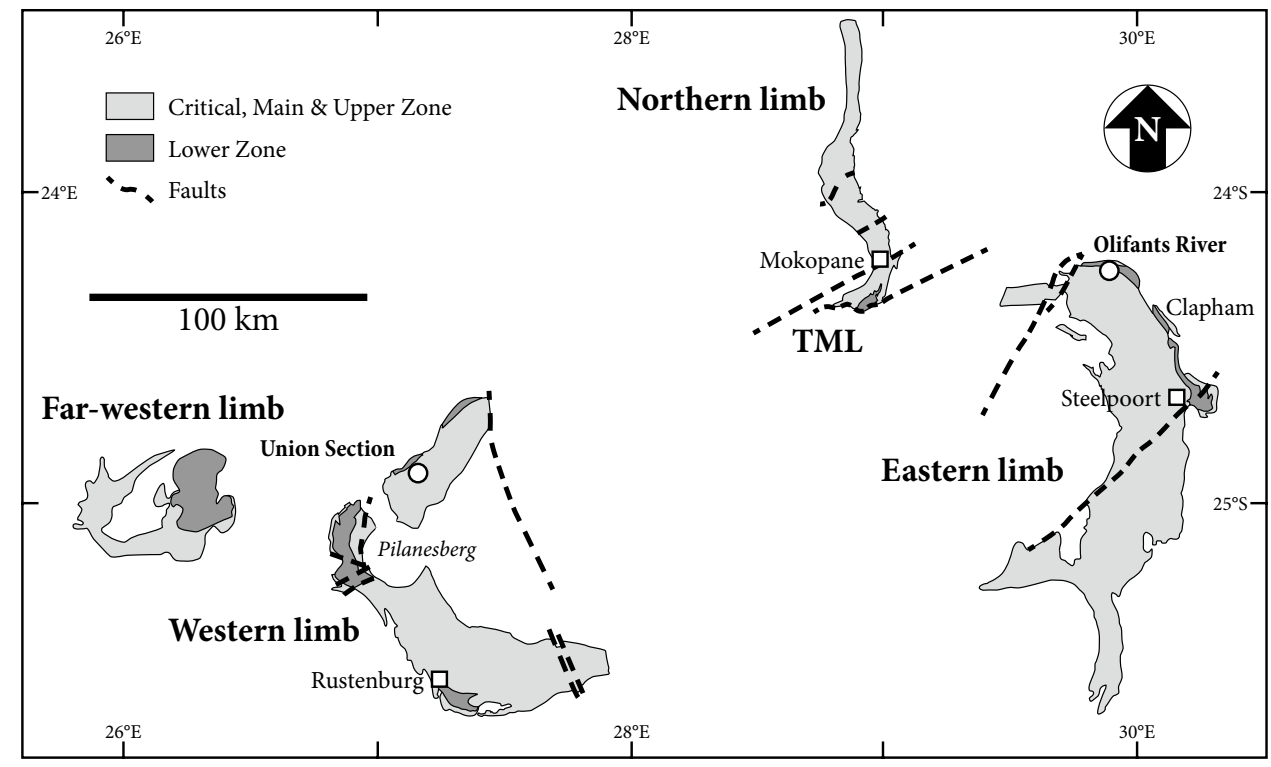



Data were taken from Teigler (1990) and Cameron (1978a). Per peridotite, $P x$ pyroxenite, No norite, ol olivine, opx orthopyroxene, oth other minerals

northern limb are rather erratic. It mostly occurs in isolated sill-like bodies with considerable changes in thickness, ranging from $<800$ to $1700 \mathrm{~m}$ over short distances, and is commonly separated from the overlying igneous succession by a distinct layer rich in floor rock xenoliths (Yudovskaya et al. 2013).

The stratigraphy of the LZ is exceptional at the Union Section as it features the first example of a chilled margin

(Fig. 1). The distribution and thickness of the LZ in the 
at the base of the LZ, consisting of a ca. 90-cm-thick chill sequence comprising Mg-rich basaltic andesite and komatiite (Maier et al. 2016a). This is overlain by a ca. 200-m-thick succession of interlayered finegrained phlogopite-rich pyroxenite, locally enriched in Pd, and medium-grained peridotite (Maier et al. 2013). Above this, a ca. 180-m-thick succession of interlayered medium-grained pyroxenite and peridotite is present, followed by ca. $140 \mathrm{~m}$ of slightly plagioclase-enriched rock types, ranging from pyroxenite to melanorite. The uppermost portion of the LZ is dominated by peridotite with minor pyroxenite (Fig. 2a).

Detailed work by Teigler (1990), Cameron (1978a) and Wilson (2015) demonstrates several significant differences between the LZ in the western and eastern limbs (Fig. 2). Besides great thickness variations, the stratigraphy is also rather dissimilar, with an olivine-dominated LZ in the west and a more orthopyroxene-rich LZ in the east. Notably, a comparison between the Olifants River and the Clapham Troughs shows that the intra-limb stratigraphy of the eastern limb is broadly consistent, but thicknesses of units vary considerably (Cameron 1978a; Wilson 2015).
Moreover, the thick pyroxenitic portion in the lower part of the LZ seems to be absent in the western limb. The Mg\# $(100 \times$ molar $\mathrm{Mg} /(\mathrm{Mg}+\mathrm{Fe}))$ of orthopyroxene mostly ranges from 84 to 90 , and shows relatively little variability across both limbs with no clear fractionation trend. This apparent lack of fractionation led to the conclusion that the LZ crystallised from a very large volume of magma (e.g. Eales and Cawthorn 1996).

\section{Layering in the Lower Zone}

Detailed examination of drill core, intersecting the LZ at the Union Section, shows mostly sharp contacts on the macroscopic scale between different lithologies, which are primarily controlled by varying modal abundances of cumulus olivine and orthopyroxene (Fig. 3a). A selection of photomicrographs highlighting the variability in rock types and textures across the LZ can be found in Electronic Appendix 1. Layering is also prominent on a smaller scale, as shown in Fig. 3b, where alternating bands of dunite and pyroxenite define the layering on the sub-cm scale, but it may locally be disrupted by abundant schlieren or fragments of pyroxenite
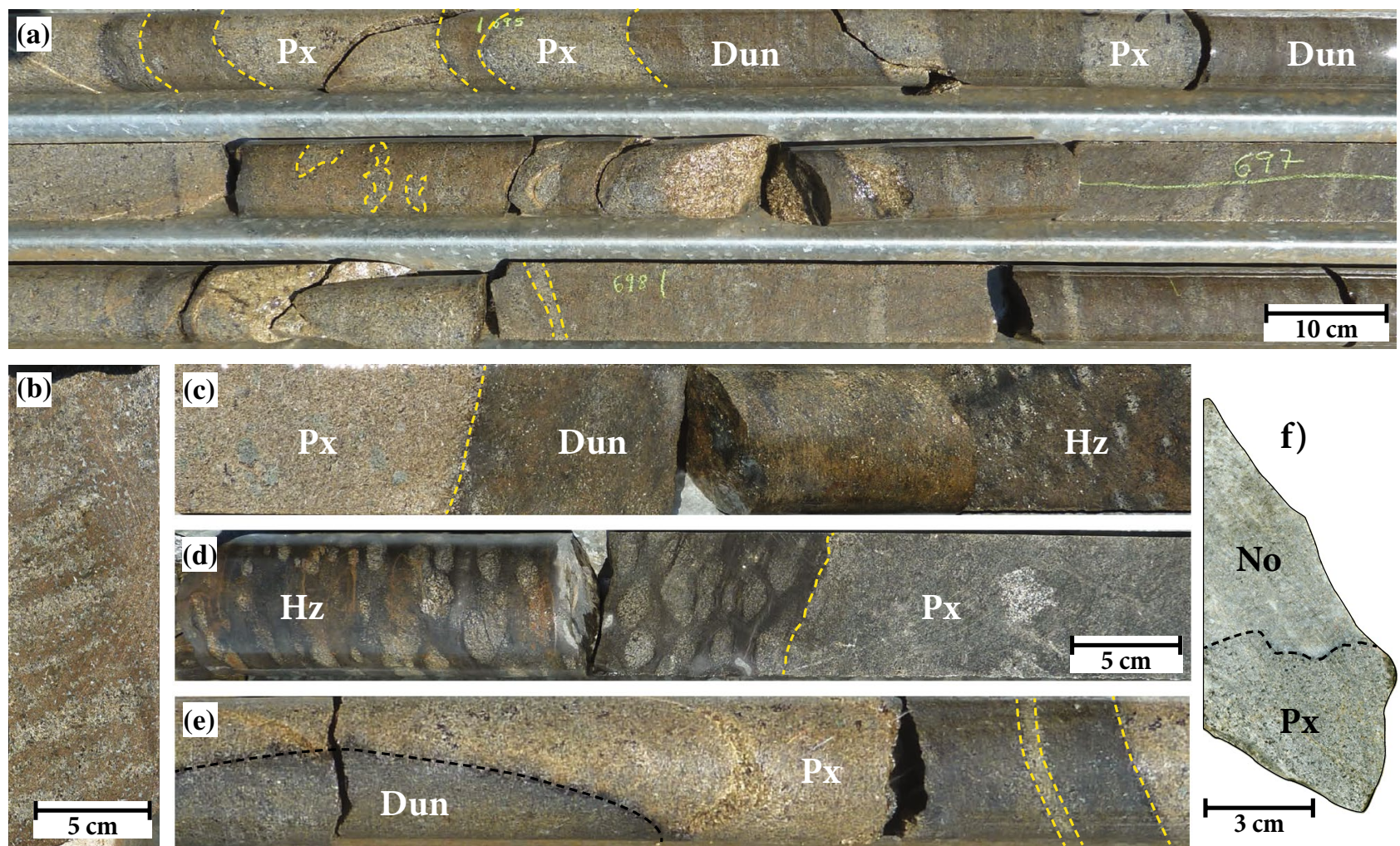

Fig. 3 Types of layering in the Lower Zone as intersected in drill core NG2 in the western Bushveld Complex. a Complex interlayering between pyroxenite and dunite. Note the small schlieren of pyroxenite in dunite. b Small-scale layering between peridotite (brown) and pyroxenite (grey). Note the dunite cutting vertically across the layered succession. c Gradual transition between poikilitic harzburgite and dunite in contact with pyroxenite. d Contact between massive pyroxenite and poikilitic harzburgite. Note that the latter represents a breccia of massive pyroxenite in an olivine-dominated matrix (black). e Dunitic layer terminating half-way across the drill core. f Noritic interval hosted by pyroxenite. The basal contact is associated with sulphide mineralisation. The core diameter is $63.5 \mathrm{~mm}(\mathrm{HQ})$ 
hosted in dunite (Fig. 3a). However, gradational contacts may also be present, and are characterised by transitions from poikilitic harzburgite to more olivine-dominated dunite, and vice versa (Fig. 3c). In places, we observe rock types that host abundant fragments from the pyroxenitic footwall in an ultramafic matrix, but contact relationships show gradual transitions from massive pyroxenite to seemingly poikilitic harzburgite, which may be interpreted to represent a magmatic breccia (Fig. 3d). Conversely, altered olivine at the contact between peridotite and pyroxenite indicates that olivine-rich lithologies do not always postdate the orthopyroxene-rich ones (Electronic Appendix 1, Fig. n).

Even though detailed inspection of drill core demonstrates the pronounced interlayering of different maficultramafic rock types, lateral variations along strike cannot be adequately evaluated without continuous outcrop or closely spaced drill holes. As a consequence of limited exposure and drill hole coverage of the LZ, the variability of individual layers along strike remains rather vaguely known in comparison to the Upper CZ. Cawthorn (2015) argued that LZ olivine-rich layers in the Olifants River Trough cannot be traced for more than a few hundred metres along strike. Furthermore, certain layers in the drill core we studied terminate half-way across the drill intersection, which strongly indicates discontinuous layering (Fig. 3e). However, a rather conspicuous norite layer of ca. $90 \mathrm{~cm}$ in thickness has been delineated in the western as well as the eastern limbs of the Bushveld Complex (Fig. 3f) (Lee and Tredoux 1986; Teigler 1990).

In summary, the LZ litho- and chemostratigraphy across the western and the eastern limbs reveals considerable lithological disparities (Fig. 2). In fact, they share very few characteristics, especially with respect to thickness and the presence of olivine-rich lithologies-only the mineral chemistry appears to be somewhat comparable. In addition, taking into account the marked variability of the LZ in the northern limb, it must be concluded that the zone is highly erratic along strike in terms of distribution, thickness, lateral continuity and lithostratigraphy (Scoon and Teigler 1995; Yudovskaya et al. 2013; Wilson 2015).

\section{Samples and analytical methods}

A set of nine samples covering the Lower Zone was collected from drill core NG2, which was collared at the Union Section of the western Bushveld Complex (Figs. 1, 4). The entire lower portion of the Bushveld Complex, i.e. Lower Zone and Lower Critical Zone, was previously described in detail by Teigler (1990).

High-resolution element maps of entire thin sections were collected using a Zeiss Sigma HD Analytical Field Emission Gun Scanning Electron Microscope (SEM) equipped with two Oxford Instruments $150 \mathrm{~mm}^{2}$ EDS detectors at Cardiff University. Mapping was performed using an accelerating voltage of $20 \mathrm{kV}, 2.5 \mathrm{nA}$ beam current, a pixel size of $8.6 \mu \mathrm{m}$ and a dwell time of $3 \mathrm{~ms}$ per pixel. Natural minerals and synthetic metals from Astimex Ltd. were used for calibration. Diopside, olivine and plagioclase from the same supplier were measured during the analytical runs to monitor instrumental drift. The modal mineralogy was determined using computed phase images, which are based on X-ray spectra collected for each pixel of the thin section. Binning of the spectra was followed by
Fig. 4 Stratigraphic column of the Lower Zone together with a plot of average in situ plagioclase (pl) and whole rock $\mathrm{Sr}$ isotope compositions, whole rock $\mathrm{Th} / \mathrm{Sm}$ ratios, average anorthite contents and $\mathrm{Pt} / \mathrm{Pd}$ ratios. Red stars indicate samples used for this study. In situ Sr isotope data were taken from Karykowski et al. (in review) and whole rock $\mathrm{Sr}$ isotope data were taken from Teigler (1990) and Maier et al. (2000), respectively. Trace element data and mineral chemistry were taken from Maier et al. (2013) and Teigler (1990), respectively. The primitive mantle (PM) $\mathrm{Th} / \mathrm{Sm}$ ratio was taken from McDonough and Sun (1995). The Pt/Pd ratio for B1 was taken from Barnes et al. (2010)

a manual phase classification of each characteristic X-ray spectrum for all phases $>0.1$ vol $\%$.

\section{Results}

The mineralogy of the analysed samples is dominated by varying proportions of euhedral olivine and orthopyroxene,



Fig. 5 Calculated mineral mode on the basis of elemental mapping. Note the gradual increase in hydrous phases within the lowermost three samples. No norite, $P x$ pyroxenite, $G n$ gabbronorite, ol olivine whereas all other minerals occur as interstitial phases within the euhedral framework (Fig. 5; Table 1).

Sample NG2-134 is a coarse-grained dunite with ca. 87 vol\% euhedral olivine and ca. 9 vol\% intercumulus plagioclase, whereas ortho- and clinopyroxene are minor intercumulus phases, accounting for less than $1 \mathrm{vol} \%$ and ca. 2 vol\%, respectively. Plagioclase shows strong compositional zonation with dramatic changes in anorthite contents from $\mathrm{An}_{78}$ to $\mathrm{An}_{45}$ over short distances-distinct subhedral anorthite-rich cores are overgrown by more albitic rims in the interstitial space (Electronic Appendix 2, Fig. A). Apatite is relatively abundant as small anhedral crystals, reaching $100 \mu \mathrm{m}$ at most. Phlogopite occurs as an accessory interstitial phase, constituting less than 1 vol\%. It is closely associated with sulphide, albite-rich plagioclase and to a lesser extent clinopyroxene.

Sample NG2-180 is a medium-grained orthopyroxenite with randomly oriented orthopyroxene accounting for ca. 89 vol\%, whereas poikilitic plagioclase and clinopyroxene reach ca. 4 and 1 vol\%, respectively. Additional interstitial phases comprise ca. 2.1 vol\% quartz, 1.5 vol\% alkali feldspar, 1.4 vol\% phlogopite and minor amphibole (Fig. 6). These interstitial minerals show a strong spatial association with each other, and with albitic plagioclase, whereas more anorthite-rich plagioclase is more abundant towards the crystal edges. Subhedral apatite is relatively abundant, reaching up to $250 \mu \mathrm{m}$ across. Moreover, a fairly large subhedral zircon crystal measuring ca. $350 \mu \mathrm{m}$ occurs in association with interstitial alkali feldspar. Another accessory mineral present is loveringite, which is a $\mathrm{Ce}-\mathrm{Zr}-\mathrm{Ti}-\mathrm{Cr}-\mathrm{rich}$

Table 1 Mineral modes of the analysed Lower Zone samples on the basis of elemental mapping

\begin{tabular}{|c|c|c|c|c|c|c|c|c|c|c|}
\hline Sample & NG2-134 & NG2-180 & NG2-300 & NG2-300 & NG2-490 & NG2-626 & NG2-664 & NG2-737 & NG2-762 & NG2-772 \\
\hline Rock type & Dun & Opx & Leuco-No & Opx & $\mathrm{Hz}$ & Ol-Opx & $\mathrm{Hz}$ & Mela-No & Mela-Gn & Ol-Gn \\
\hline Strat. height (m) & 639 & 593 & 473 & 473 & 283 & 147 & 109 & 36 & 11 & 1 \\
\hline Opx (vol\%) & 0.6 & 89.2 & 21.5 & 86.5 & 51.2 & 60.5 & 15.4 & 80.6 & 63.5 & 37.3 \\
\hline $\mathrm{Ol}(\mathrm{vol} \%)$ & 87.3 & - & - & - & 39.8 & 29.4 & 74.9 & - & 0.1 & 26.3 \\
\hline Cpx (vol\%) & 1.9 & 1.2 & - & 2.1 & 1.7 & 1.5 & 1.5 & 2.4 & 7.7 & 7.6 \\
\hline $\mathrm{Pl}$ (vol\%) & 8.6 & 4.2 & 78.5 & 7.2 & 5.5 & 6.7 & 2.0 & 16.4 & 19.8 & 21.6 \\
\hline Chr (vol\%) & 0.6 & - & - & - & 0.4 & 0.6 & 0.1 & - & 0.1 & - \\
\hline Qtz (vol\%) & - & 2.1 & - & - & - & - & - & - & 2.9 & - \\
\hline Kfs (vol\%) & - & 1.5 & - & $<0.1$ & - & - & - & - & - & - \\
\hline Phl (vol\%) & 0.8 & 1.4 & $<0.1$ & 0.5 & 0.9 & 0.9 & 5.6 & 0.4 & 5.8 & 5.0 \\
\hline Amph (vol\%) & 0.1 & 0.3 & $<0.1$ & 3.7 & 0.4 & 0.4 & 0.6 & 0.2 & 0.2 & 2.1 \\
\hline Total & 100.0 & 100.0 & 100.0 & 100.0 & 100.0 & 100.0 & 100.0 & 100.0 & 100.0 & 100.0 \\
\hline Ap & ++ & ++ & + & + & ++ & ++ & ++ & +++ & +++ & +++ \\
\hline Lov & - & + & - & - & - & - & - & + & + & - \\
\hline $\mathrm{Zrc}$ & - & + & - & - & - & - & - & - & - & - \\
\hline
\end{tabular}

Lithologies: Dun dunite, $\mathrm{Hz}$ harzburgite, $\mathrm{Opx}$ orthopyroxenite, No norite, $\mathrm{Gn}$ gabbronorite, $\mathrm{Ol}$ olivine

Minerals: $O p x$ orthopyroxene, $O l$ olivine, $c p x$ clinopyroxene, $P l$ plagioclase, $C h r$ chromite, $Q t z$ quartz, $K f s$ alkali feldspar, $P h l$ phlogopite, Amph amphibole, $Q t z$ quartz, $K f s$ alkali feldspar, $P h l$ phlogopite, Amph amphibole, Ap apatite, Lov loveringite, $Z r c$ zircon 
Fig. 6 Elemental map of orthopyroxenite NG2-180. opx orthopyroxene, $c p x$ clinopyroxene, qtz quartz, $p l$ plagioclase, $p h l$ phlogopite, $k f s$ alkali feldspar, zrc zircon
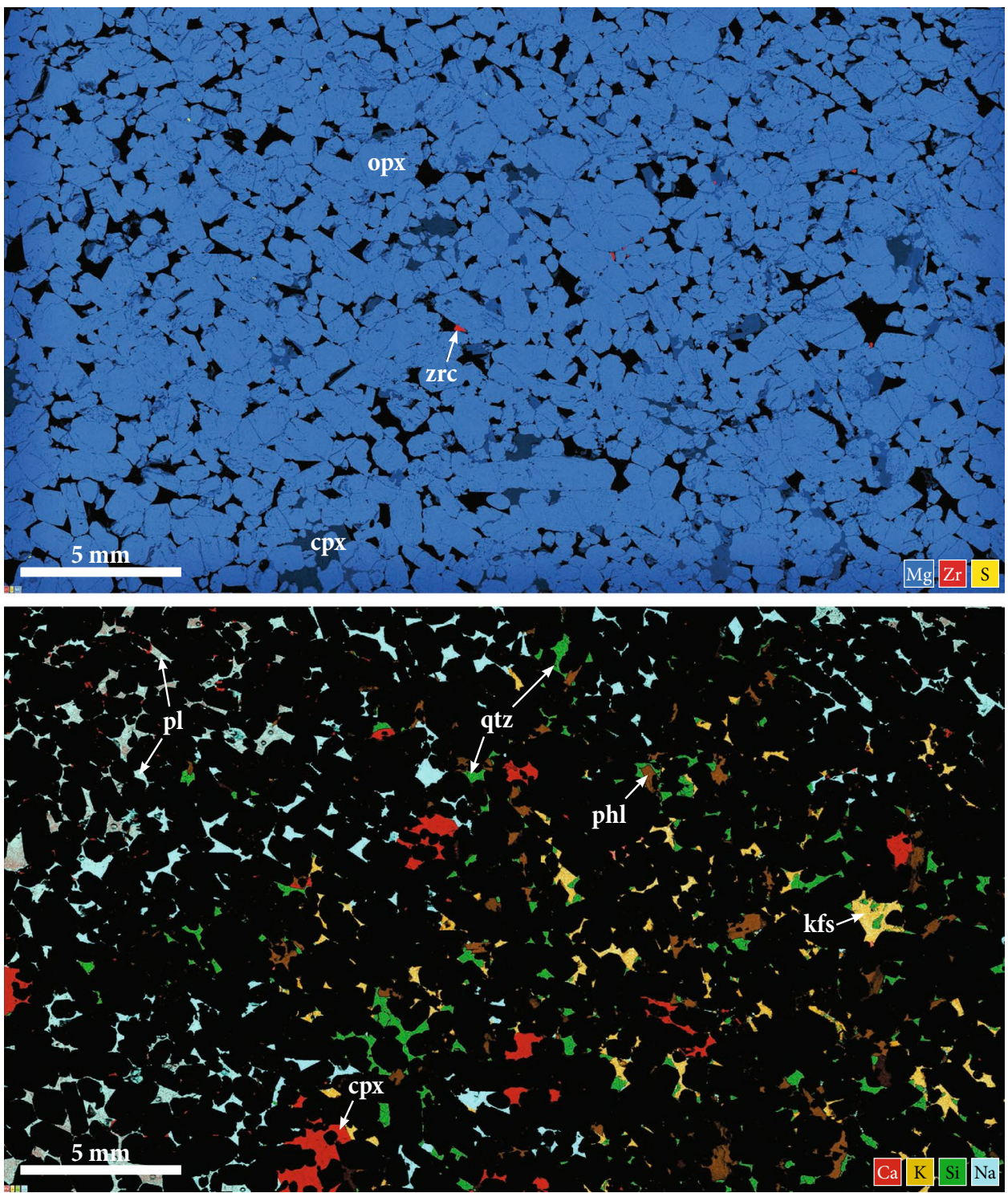

oxide mineral, belonging to the crichtonite group (Gatehouse et al. 1978). It is present as a rather small, subhedral grain, reaching up to $200 \mu \mathrm{m}$ across (Fig. 12a).

Sample NG2-300 represents the lower contact between a medium-grained leuconorite and the medium-grained pyroxenitic footwall. The latter consists of ca. $87 \mathrm{vol} \%$ euhedral orthopyroxene, 7 vol\% plagioclase and 2 vol\% clinopyroxene. Other interstitial phases include ca. 4 vol\% amphibole, less than 1 vol\% phlogopite and accessory alkali feldspar. Plagioclase shows a relatively strong chemical zonation from the immediate contact into the footwall, where phlogopite is also more abundant (Fig. 7). Apatite crystals are generally rare, reaching $450 \mu \mathrm{m}$ at most. Notably, the pyroxenite also hosts abundant sulphide mineralisation occurring as fine disseminations throughout the rock. The contact between the two rock types is marked by a sub-mm-thick band of chromite, which follows the undulating contact. The thickness of the chromite band shows considerable lateral variation across the thin section, locally splicing into two sub-bands. The overlying leuconorite is weakly layered and composed of ca. 78 vol\% subhedral to euhedral plagioclase and ca. $21 \mathrm{vol} \%$ anhedral to euhedral orthopyroxene. Accessory minerals include clinopyroxene and sulphide, which is generally less abundant in comparison to the underlying pyroxenite. The fabric of the leuconorite follows broadly the undulating contact marked by the chromite band.

Sample NG2-490 is a massive harzburgite, consisting of ca. 51 vol\% orthopyroxene and 40 vol\% olivine, with accessory chromite and sulphide. Clinopyroxene is present as patchy oikocrysts throughout the thin section, accounting for less than $2 \mathrm{vol} \%$. Plagioclase is more abundant, constituting ca. $6 \mathrm{vol} \%$, and shows considerable chemical variation, although distinct core-rim compositional relationships are not evident (Electronic Appendix 2, Fig. D). 
Fig. 7 Elemental map of sample NG2-300 showing a sharp contact between leuconorite and orthopyroxenite. The top of the image indicates stratigraphic up. opx orthopyroxene, $c p x$ clinopyroxene, $c h r$ chromite, $p l$ plagioclase, $k f s$ alkali feldspar, phl phlogopite, ap apatite, sul sulphide
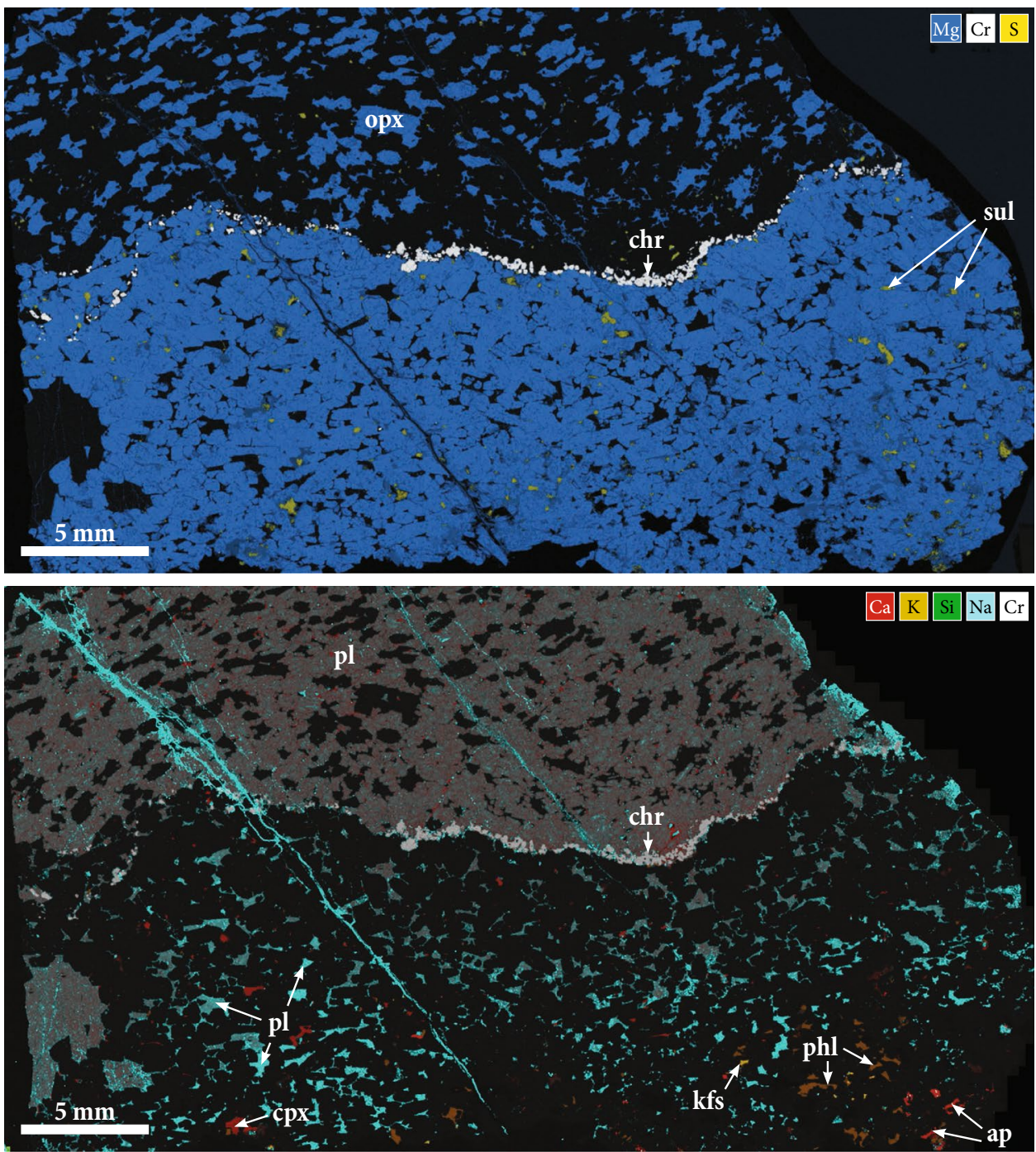

Phlogopite occurs in a relatively confined area of the thin section, reaching up to $1 \mathrm{vol} \%$, together with abundant interstitial anhedral to subhedral apatite of up to $300 \mu \mathrm{m}$ in length. Notably, the sample contains a tabular megacryst of inclusion-poor orthopyroxene, which is similar in composition to smaller orthopyroxene grains surrounding it.

Sample NG2-626 is a weakly layered olivine-orthopyroxenite with ca. 61 vol\% orthopyroxene and 29 vol\% olivine; minor patches of poikilitic clinopyroxene constitute less than 2 vol\% (Electronic Appendix 2, Fig. E). Plagioclase occurs as an interstitial phase and accounts for ca. 7 vol\%. It shows relatively pronounced compositional zonation with anorthite-rich subhedral cores and more albitic anhedral rims. Apatite is relatively abundant; it occurs as small anhedral grains, reaching up to $200 \mu \mathrm{m}$ and is closely associated with phlogopite and amphibole, which account for less than $1 \mathrm{vol} \%$ combined.

Sample NG2-664 is a harzburgite, containing ca. 75 vol\% euhedral olivine, 15 vol\% intercumulus orthopyroxene, less than $4 \%$ plagioclase plus clinopyroxene, as well as minor chromite and amphibole. Phlogopite is relatively abundant, reaching almost 6 vol\%, and anhedral to subhedral apatite occurs as an accessory phase of up to $250 \mu \mathrm{m}$ in length, commonly enclosed by orthopyroxene (Electronic Appendix 2, Fig. F). All the interstitial phases are concentrated in distinct pod-like areas of the thin section, rather than being homogeneously distributed throughout the sample.

Sample NG2-737 is a melanorite with ca. 81 vol\% euhedral orthopyroxene, 16 vol\% plagioclase and minor clinopyroxene. Accessory phases are phlogopite and amphibole, accounting for less than 1 vol\% combined. Interstitial plagioclase shows considerable chemical zonation with anorthite-rich cores and more albitic rims (Electronic Appendix 2, Fig. G). The sample also contains significant amounts of subhedral apatite, reaching up to $320 \mu \mathrm{m}$ across, and less commonly loveringite of up to $250 \mu \mathrm{m}$.

Sample NG2-762 is a fine- to medium-grained melagabbronorite with a predominance of prismatic orthopyroxene 
over clinopyroxene, and with accessory olivine and chromite. Clinopyroxene occurs as randomly distributed oikocrysts together with strongly zoned plagioclase. Despite the interstitial texture of the latter, the compositional variation commonly shows distinct euhedral anorthite-rich plagioclase cores, which are overgrown by more albitic rims (Fig. 8). Another striking feature is the abundance of phlogopite, constituting up to $6 \mathrm{vol} \%$. It occurs in large interstitial patches spatially associated with subhedral to euhedral prismatic apatite grains of up to $800 \mu \mathrm{m}$ in length, as well as anhedral quartz, which accounts for ca. 3 vol\%. The sample also contains subhedral loveringite grains of up to $200 \mu \mathrm{m}$ in length, as well as small amounts of sulphide (Fig. 12b).

Sample NG2-772 is a fine-grained olivine-gabbronorite situated ca. $1.4 \mathrm{~m}$ away from the floor rock contact of the intrusion. Olivine and plagioclase account for ca. 26 and $22 \mathrm{vol} \%$, respectively, whereas orthopyroxene is slightly more abundant with 37 vol\%. Phlogopite and amphibole reach ca. 5 and 2 vol\%, respectively. The latter is closely associated with clinopyroxene rims, whereas phlogopite occurs as irregular patches throughout the rock. Moreover, the sample contains minor anhedral apatite and minor sulphide, both of which are confined to interstices
(Electronic Appendix 2, Fig. Ia). Compositional zonation in plagioclase is fairly pronounced, mostly showing anorthite-rich cores and more albitic rims.

The analysed LZ sample set covers a wide lithological range from ultramafic to mafic compositions, i.e. dunite, harzburgite, orthopyroxenite, leuco- and melanorite and melagabbronorite. The total modal amount of interstitial phases is highly variable across the LZ and the relative proportions of clinopyroxene, plagioclase, alkali feldspar and hydrous phases comprising the interstitial mineral assemblage also change dramatically irrespective of the host cumulate. Some ultramafic rocks are essentially barren of evolved or hydrous minerals, whereas others host significant amounts of these phases.

\section{Discussion}

\section{Melt migration}

To estimate the mineral proportions expected to crystallise from a patch of trapped liquid in equilibrium with cumulus orthopyroxene in a typical LZ pyroxenite, we conducted
Fig. 8 Elemental map of melagabbronorite sample NG2762. opx orthopyroxene, $c p x$ clinopyroxene, $p l$ plagioclase, $q t z$ quartz, $p h l$ phlogopite, ap apatite, sul sulphide
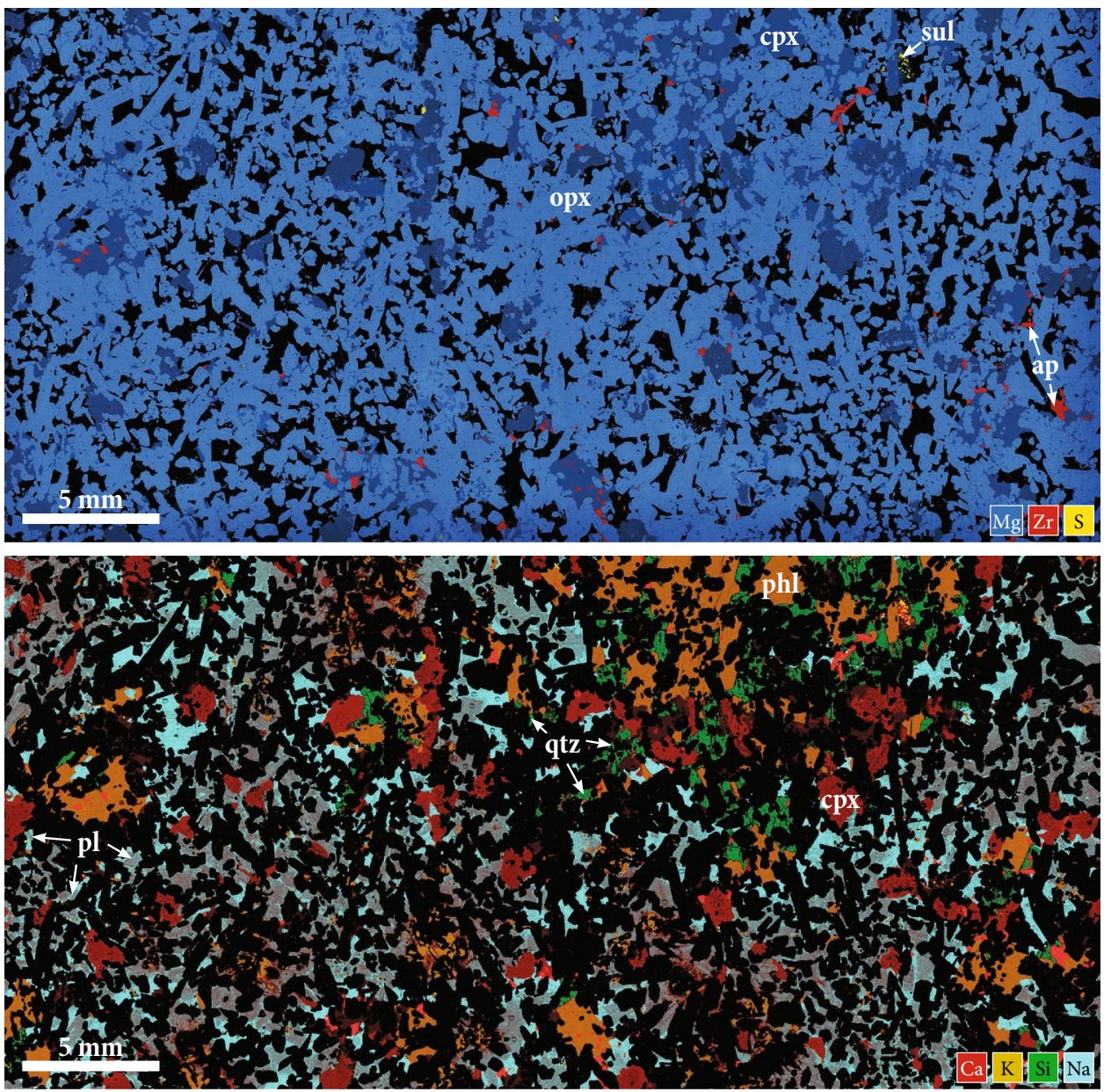
fractional crystallisation modelling, assuming a Bushveld B1 magma from Barnes et al. (2010), which has undergone fractional crystallisation up to the point where orthopyroxene compositions match the ones observed in the LZ. Subsequently, the residual liquid trapped in the interstitial space of the cumulus mineral framework crystallised in local equilibrium between phases under closed-system conditions. PELE (Boudreau 1999) modelling shows that fractional crystallisation of a slightly hydrous B1 magma with ca. $12 \mathrm{wt} \% \mathrm{MgO}\left(0.05 \mathrm{wt} \% \mathrm{H}_{2} \mathrm{O}\right)$ at 1200 bar produces orthopyroxene compositions similar to the ones in the LZ $(\mathrm{Mg} \# \sim 83)$ after ca. 35\% crystallisation, which would be in equilibrium with a residual liquid of ca. $5.4 \mathrm{wt} \% \mathrm{MgO}$. Trapping of this liquid and subsequent closed-system equilibrium crystallisation would result in an interstitial mineral assemblage comprising ca. 49 vol\% plagioclase, $13 \mathrm{vol} \%$ clinopyroxene, 17 vol\% quartz and 21 vol\% of other minerals including alkali feldspar and phlogopite, assuming that orthopyroxene crystallised as a relatively evolved overgrowth or rim on pre-existing cumulus grains (Table 2). The initial water content of the magma does not play a significant role in the calculations, as it primarily controls the ratio between phlogopite and alkali feldspar; this has a negligible effect on the model, due to the small difference in density of less than $10 \%$. However, the most realistic ratio between phlogopite and alkali feldspar based on the observed mineral proportions of the analysed LZ samples resulted from modelling with an initial water content of $<0.1 \mathrm{wt} \% \mathrm{H}_{2} \mathrm{O}$. Above this value, phlogopite dominates significantly over alkali feldspar, which is inconsistent with our observations.

Using the relative mineral proportions that are expected to crystallise from trapped liquid under closed-system equilibrium (plagioclase:clinopyroxene:all other late stage minerals $=49: 13: 38$ ), the trapped liquid fraction can be estimated on the basis of measured plagioclase and clinopyroxene modes, respectively. For example, orthopyroxenite sample NG2-300 features an interstitial mineral assemblage of $7.2 \mathrm{vol} \%$ plagioclase, $2.1 \mathrm{vol} \%$ clinopyroxene and 4.2 vol\% other late stage minerals (Table 3 ). Based on the plagioclase mode of this sample, the estimated trapped liquid fraction would be $41 \mathrm{vol} \%$, while the clinopyroxene mode would suggest a slightly higher trapped liquid fraction of $46 \mathrm{vol} \%$. In comparison to that, the late stage phases account for only $31 \mathrm{vol} \%$ of the interstitial mineral mode.

The results of this calculation for all other analysed LZ samples are shown in Table 3. The dataset shows that the trapped liquid estimates, derived from plagioclase and clinopyroxene modes, are generally higher compared to what the late stage mineral mode would suggest, except for two unusually phlogopite-rich samples (orthopyroxenite NG2-180, harzburgite NG2-664).
Table 2 Results of equilibrium crystallisation of trapped melt using PELE

\begin{tabular}{|c|c|c|}
\hline Mineral & $\begin{array}{l}\text { Equilibrium mineral } \\
\text { mode }\end{array}$ & $\begin{array}{l}\text { Interstitial mineral } \\
\text { mode }^{\mathrm{a}}\end{array}$ \\
\hline Orthopyroxene (vol\%) & 12.1 & - \\
\hline Clinopyroxene (vol\%) & 11.1 & 12.6 \\
\hline Plagioclase (vol\%) & 43.2 & 49.1 \\
\hline Quartz (vol\%) & 14.9 & 17.0 \\
\hline Other minerals (vol\%) & 18.7 & 21.3 \\
\hline Total & 100.0 & 100.0 \\
\hline
\end{tabular}

Melt composition: B1 magma from Barnes et al. (2010), which has undergone fractional crystallisation up to the point where orthopyroxene compositions match the ones observed in the $\mathrm{LZ}\left(\mathrm{En}_{85}\right)$. Conditions: $1.2 \mathrm{kbar} ; f \mathrm{O}_{2}=\mathrm{QFM}$

a Assuming that orthopyroxene crystallised as an overgrowth on cumulus orthopyroxene

Similar trapped liquid estimates based on plagioclase and clinopyroxene modes would be somewhat expected, as they are close to each other along the liquid line of descent, whereas the other phases, especially the hydrous minerals, crystallise very late.

The disparity between these estimates cannot be explained by closed-system fractionation, but requires a substantial loss of evolved trapped liquid from the cumulate after the crystallisation of plagioclase and clinopyroxene. A feasible mechanism to allow for trapped liquid to be lost during late stages of cumulate solidification could be compaction-driven melt migration (Meurer and Boudreau 1996; Boorman et al. 2004). The two phlogopite-rich samples, however, demonstrate that evolved trapped liquid in these systems can also be gained and not only lost: trapped liquid estimations derived from plagioclase and clinopyroxene modes in orthopyroxenite sample NG2-180 suggest $30 \mathrm{vol} \%$ and $33 \mathrm{vol} \%$ trapped liquid, respectively, whereas late stage minerals account for $50 \mathrm{vol} \%$ of the mode. Compared with this, plagioclase and clinopyroxene modes in harzburgite sample NG2-664 suggest highly dissimilar estimates of trapped liquid with 16 and $45 \mathrm{vol} \%$, respectively.

Thus, it is more likely that the trapped liquid was removed from its original location within the cumulate at different stages of crystallisation through expulsion as a consequence of either compaction or displacement by convecting interstitial liquids (Fig. 9a, b). Expelled melts that migrated through the cumulate were characterised by variable degrees of fractionation, implying that evolved melts can be replaced by relatively primitive melts and vice versa.

It may be argued that orthopyroxenite sample NG2-180 has an unusually felsic interstitial mineral assemblage, as it is also characterised by a more radiogenic $\mathrm{Sr}$ isotope composition of plagioclase (Fig. 4), potentially reflecting 
Table 3 Trapped liquid estimates

\begin{tabular}{|c|c|c|c|c|c|c|c|c|c|c|}
\hline \multirow[t]{2}{*}{ Sample } & \multirow[t]{2}{*}{ Rock type } & \multicolumn{3}{|c|}{ Interstitial mineral mode } & \multicolumn{3}{|c|}{$\begin{array}{l}\text { Normalised mineral } \\
\text { mode }\end{array}$} & \multicolumn{3}{|c|}{$\begin{array}{l}\text { Estimated trapped } \\
\text { liquid }^{\text {a }}\end{array}$} \\
\hline & & $\mathrm{Pl}$ & Cpx & Oth & $\mathrm{Pl}$ & Cpx & Oth & $\mathrm{Pl}$ & Cpx & Oth \\
\hline NG2-134 & Dun & 8.6 & 1.9 & 0.9 & 75.4 & 16.7 & 7.9 & 58.5 & 48.7 & 7.9 \\
\hline NG2-180 & Opx & 4.2 & 1.2 & 5.3 & 39.3 & 11.2 & 49.5 & 30.4 & 32.8 & 49.5 \\
\hline NG2-300 & Opx & 7.2 & 2.1 & 4.2 & 53.3 & 15.6 & 31.1 & 41.4 & 45.5 & 31.1 \\
\hline NG2-490 & $\mathrm{Hz}$ & 5.5 & 1.7 & 1.3 & 64.7 & 20.0 & 15.3 & 50.2 & 58.5 & 15.3 \\
\hline NG2-626 & Ol-Opx & 6.7 & 1.5 & 1.3 & 70.5 & 15.8 & 13.7 & 54.7 & 46.2 & 13.7 \\
\hline NG2-664 & $\mathrm{Hz}$ & 2.0 & 1.5 & 6.2 & 20.6 & 15.5 & 63.9 & 16.0 & 45.2 & 63.9 \\
\hline NG2-737 & Mela-No & 16.4 & 2.4 & 0.6 & 84.5 & 12.4 & 3.1 & 65.6 & 36.2 & 3.1 \\
\hline NG2-762 & Mela-Gn & 19.8 & 7.7 & 8.9 & 54.4 & 21.2 & 24.5 & 42.2 & 61.8 & 24.5 \\
\hline NG2-772 & Ol-Gn & 21.6 & 7.6 & 7.1 & 59.5 & 20.9 & 19.6 & 46.1 & 61.2 & 19.6 \\
\hline
\end{tabular}

Lithologies: Dun dunite, $\mathrm{Hz}$ harzburgite, $\mathrm{Opx}$ orthopyroxenite, No norite, $\mathrm{Gn}$ gabbronorite, $\mathrm{Ol}$ olivine Minerals: $P l$ plagioclase, $C p x$ clinopyroxene, Oth other minerals

a Assuming a ratio of pl:cpx:all other late stage minerals $=49: 13: 38$ (modelled equilibrium assemblage) interstitial melt compositions that were not derived from a mafic-ultramafic parental magma, but from felsic partial melts. On the other hand, sample NG2-134 also features an enriched $\mathrm{Sr}$ isotope signature, despite a typical mafic interstitial mineral assemblage (Table 1; Electronic Appendix 2, Fig. A). Hence, radiogenic $\mathrm{Sr}$ isotope compositions are not exclusive to a felsic interstitial mineral assemblage, which supports a mafic-ultramafic origin of the interstitial material in sample NG2-180. In addition, these more radiogenic samples show no evidence for a larger crustal component, as indicated by their $\mathrm{Th} / \mathrm{Sm}$ ratios, which are largely in line with those of the other samples (Fig. 4).

Further support for commonly occurring melt convection is provided by the highly variable incompatible trace element abundances across the LZ (Fig. 10). A plot of whole rock La concentrations vs. the amount of trapped liquid indicates that most of the LZ samples have either lost or gained residual liquid relative to what would be expected from trapped liquid crystallisation of B1 magma under closed-system conditions.

\section{Emplacement of the Lower Zone as a sill complex}

The presence of discontinuous layering in the LZ, together with the major lateral variations along strike in terms of distribution, thickness and lithotypes as well as the heterogeneous $\mathrm{Sr}$ isotope compositions and the erratic $\mathrm{Pt} /$ $\mathrm{Pd}$ ratios across the sequence, argues strongly against a classical closed-system fractionation model (Figs. 3, 4) (Cameron 1978a; Teigler 1990; Yudovskaya et al. 2013; Karykowski et al., in review). Additionally, the lack of progressive fractionation, as indicated by the near-constant $\mathrm{Mg \#}$ of orthopyroxene across an interval of up to $1500 \mathrm{~m}$, is also inconsistent with closed-system crystallisation (Fig. 2). Notably, several geochemical characteristics of the uppermost $\mathrm{LZ}$ peridotites provide further arguments against normal fractionation (Fig. 4). Olivines from these samples have the highest forsterite contents of all LZ lithologies, implying that they crystallised from the most primitive magma (Teigler 1990). Additionally, these peridotites are characterised by much lower PGE and $\mathrm{Cu}$ concentrations compared to the rest of the LZ (Maier et al. 2013). Together with mantle-like $\mathrm{Cu} / \mathrm{Pd}$ ratios and $\mathrm{Cu} / \mathrm{Zr}$ ratios close to unity throughout the unit, this suggests a crystallisation from a sulphur-undersaturated magma, even though all other LZ lithologies, including the footwall, show evidence for cumulus sulphide, and thus for a crystallisation from a sulphur-saturated parental magma (Maier et al. 2013).

The contact relationship between the LZ pyroxenite and ca. 90-cm-thick noritic interval sampled in NG2-300 provides an insight into the processes associated with the formation of this rather unusual noritic package. The sharp undulating contact shown in Fig. 7 is broadly parallel to the fabric defined by the orthopyroxene crystals in the leuconorite. Moreover, the contact is marked by a thin chromite seam, which may be interpreted as a reaction product, resulting from the partial melting of the footwall pyroxenite in a process similar to the petrogenetic model for the Merensky Reef proposed by Nicholson and Mathez (1991). Interstitial sulphide mineralisation associated with the lower rather than the upper contact of the noritic interval indicates that these sulphides were introduced as part of the leuconorite. These observations are best explained by a sill model in which the leuconorite intruded as a sulphursaturated crystal mush with cumulus plagioclase and minor orthopyroxene, which led to local melting of the pyroxenite to form the chromite band. Residual melt and dense sulphide liquid locally percolated downwards into the footwall pyroxenite, as evidenced by the relatively high abundance of sulphides. 
Fig. 9 a Formation of intercumulus minerals from trapped liquid. Euhedral to subhedral plagioclase crystallises with a distinct geochemical and isotopic signature in the interstitial space. The residual liquid may be forced upwards as a consequence of compaction or displacement by a different migrating liquid. b Infiltration of the cumulate by a geochemically and isotopically distinct batch of liquid from elsewhere in the crystal pile results in distinct overgrowths on pre-existing plagioclase grains. Upon further fractionation of the interstitial liquid, evolved phases, such as quartz, phlogopite, alkali feldspar, start crystallising. c Schematic diagram illustrating the effect of floor rock topography on the geometry of the Lower Zone. The spatial distribution of geochemically distinct sills is controlled by bulges and troughs in the floor rock, i.e. the lowermost pyroxenite unit is only present in the Olifants River Trough. Note that the noritic interval cross-cuts the ultramafic succession in the western and eastern limbs
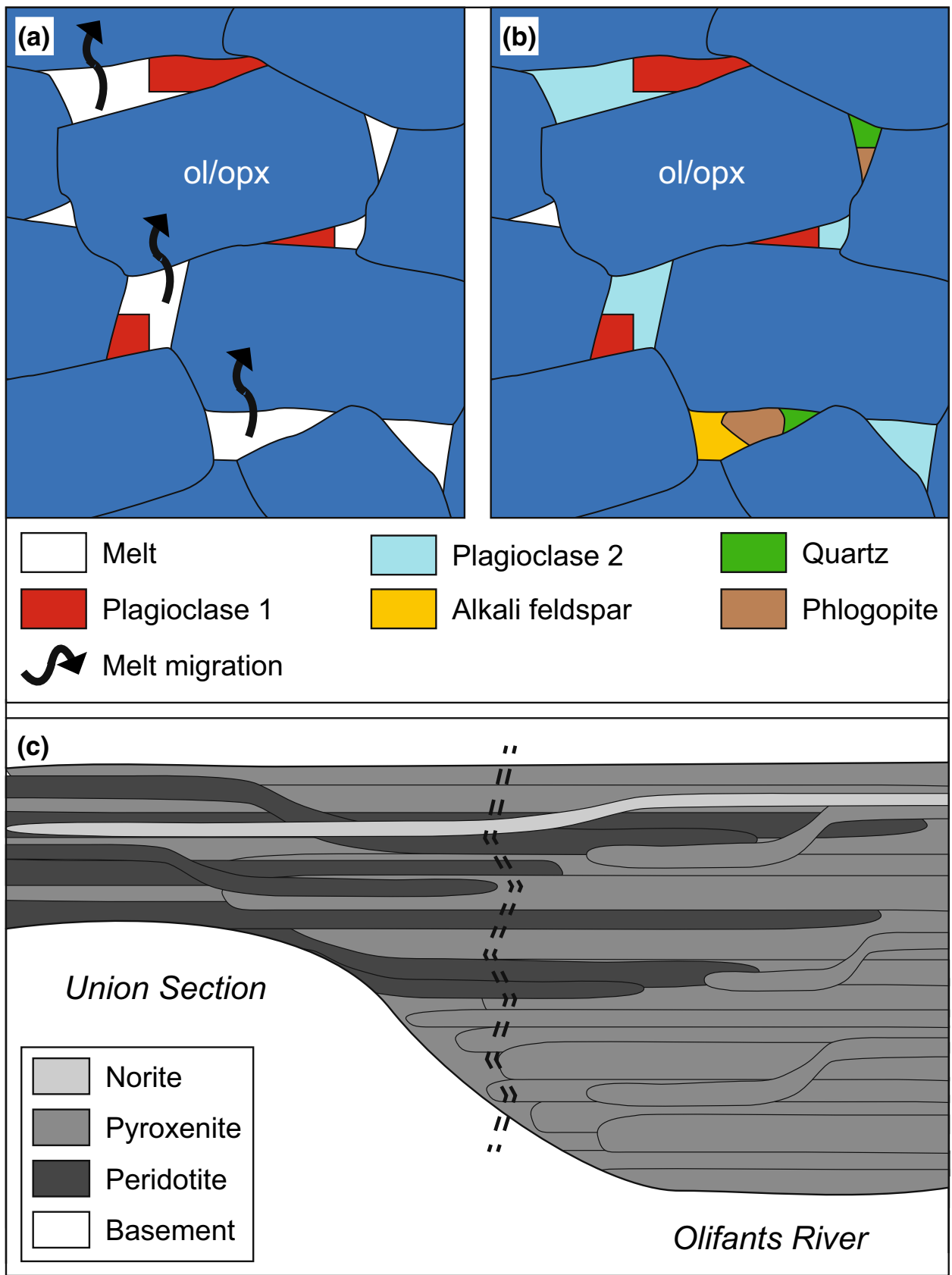

The diverse geochemical character of the LZ lithologies likely resulted from the crystallisation of cumulus minerals in a sub-Bushveld staging chamber that episodically fed variably contaminated crystal mushes into the LZ, as suggested by Ashwal et al. (2005). This staging chamber would have been large enough to allow for the crystallisation of considerable amounts of orthopyroxene showing limited variability in $\mathrm{Mg} \#$.

A number of studies have previously suggested an intrusive sill-like emplacement of other parts of the Bushveld Complex, based mainly on the presence of large floor rock xenoliths between the LZ and the UCZ
(Hulbert 1983; Maier et al. 2008; Yudovskaya et al. 2013). Furthermore, transgressive anorthosite seams in the Upper CZ were also interpreted to inject in a sill-like manner (Maier et al. 2016b). The well-exposed Monchegorsk Complex in Arctic Russia may represent an analogue to what can be observed in other layered intrusions. The ultramafic Sopcha intrusion shows distinct macroscopic interlayering between two pyroxenitic lithologies of contrasting colour. In most places, the greenish upper layer defines a sharp undulating contact similar to layering in other intrusions (Fig. 11a). However, further along strike, this layer has bifurcated into a complex 


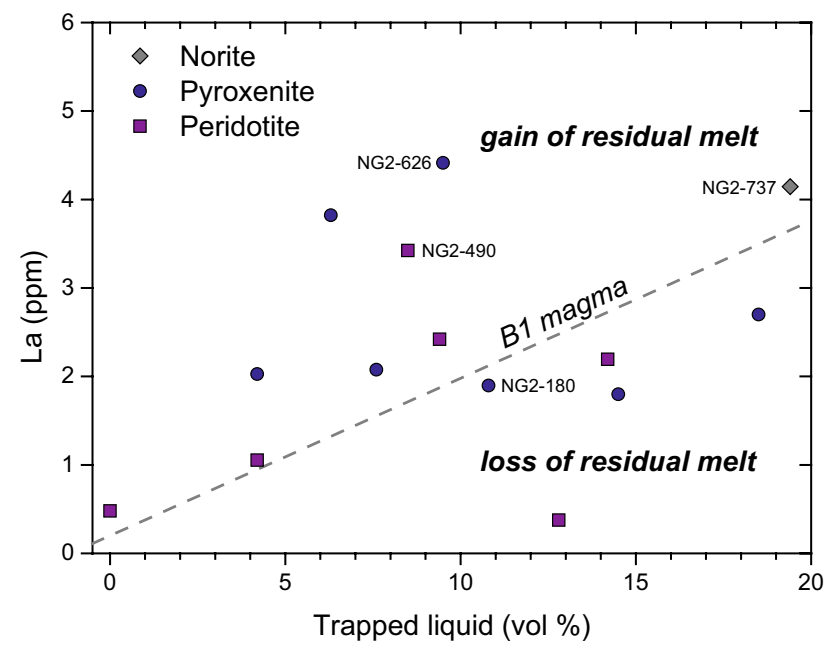

Fig. 10 Plot of whole rock La concentrations vs. trapped liquid. The trapped liquid component was estimated on the basis of the intercumulus mineral abundance in each sample. Note that most samples plot away from the dashed orthopyroxene-B1 magma tie-line. Data were taken from Teigler (1990), Maier et al. (2013) and this study. The La concentrations of B1 magma and LZ orthopyroxene were taken from Barnes et al. (2010) and Godel et al. (2011), respectively

set of sub-layers that interfinger with the host pyroxenite (Fig. 11b). Notably, these two lithologies are geochemically very similar, but the brownish host pyroxenite is extensively mineralised, accounting for why it can be visually discerned relative to the greenish one, whereas in most other cases this highly revealing feature is absent.

As a consequence, we suggest that bifurcation is a ubiquitous process at least within the LZ, accounting for the observed discontinuous layering, and allowing for the presence of sulphide-undersaturated lithologies above saturated ones with distinct $\mathrm{Pt} / \mathrm{Pd}$ ratios, possibly even across the entire Bushveld Complex. It is only apparent in successions characterised by visually distinctive and contrasting lithologies, i.e. xenolith-rich intervals, anorthosite/chromite seams, unusual noritic or sulphidic intervals. The lateral variations across the different limbs are thus strongly controlled by floor rock topography, which affected the spatial distribution and propagation of individual sills (Fig. 9c).

\section{Accessory minerals in the Lower Zone}

According to Webster and Piccoli (2015), magmatic apatite occurs predominantly in two different crystal habits, either as equant to sub-equant or as acicular grains. Moreover, Tollari et al. (2008) showed that the most important controls on apatite saturation in mafic systems are $\mathrm{SiO}_{2}$ and $\mathrm{CaO}$ concentrations, together with temperature, as the apatite solubility strongly increases with decreasing silica contents or degrees of polymerisation, and with increasing temperature (Piccoli and Candela 2002). In most mafic-ultramafic layered intrusions, apatite only becomes a cumulus phase relatively late in the crystallisation history. For example in the Upper Zone of the Bushveld Complex, in the Jameson Range of the Giles Complex and at Skaergaard, apatite saturation occurs together with $\mathrm{Fe}-\mathrm{Ti}$ oxides in evolved ferrogabbros, locally producing nelsonite (Wager 1960; Tegner et al. 2006; Karykowski et al. 2017).

The occurrence of acicular apatite, together with quartz, phlogopite and albitic plagioclase in a melagabbronorite close to the basal contact of the intrusion (sample NG2762) suggests a magmatic origin under rapid-cooling conditions (Fig. 12c) (Webster and Piccoli 2015). In contrast, subhedral to euhedral apatite from melanorite sample NG2737, together with non-cotectic proportions of evolved phases, such as quartz, phlogopite and alkali feldspar, provides little evidence for its late stage crystallisation from trapped liquid (Fig. 12d). It is more likely that the apatite initially grew more or less freely in the interstitial space, but the most fractionated portion of the melt was expelled
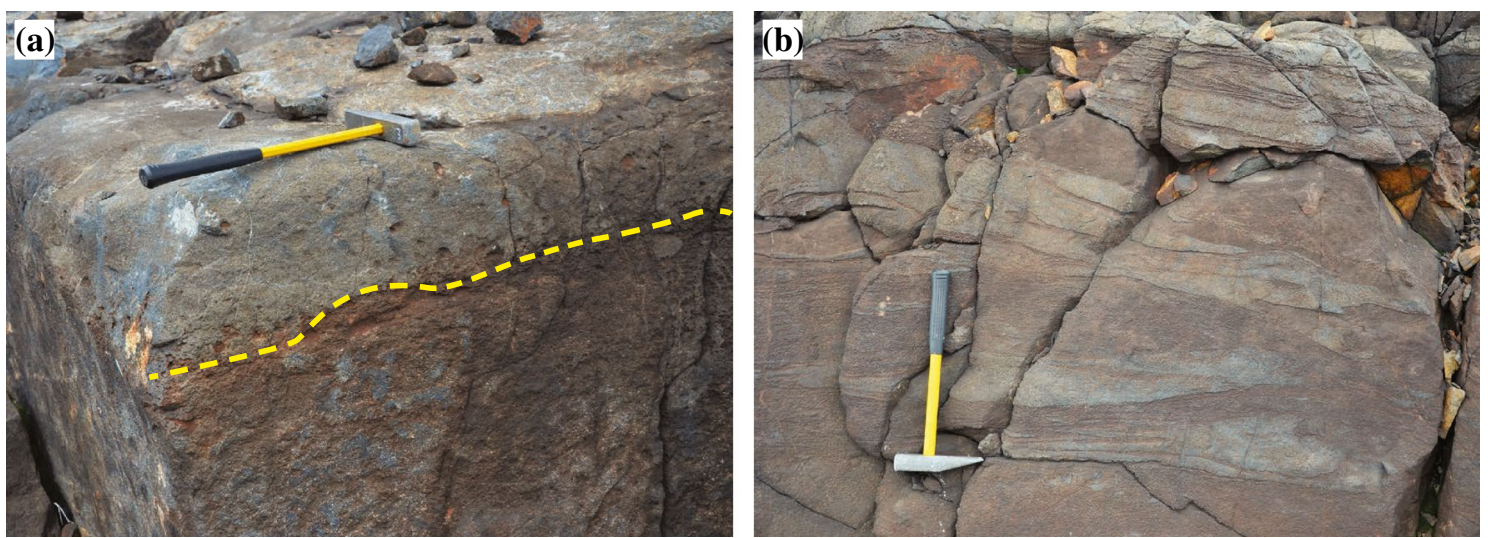

Fig. 11 Exposure of layered pyroxenite in the Monchegorsk Complex, NW Russia. a Sharp boundary between greenish pyroxenite and the underlying mineralised brownish pyroxenite. b Splicing of the greenish pyroxenite results in complex interlayering between the two rock types 

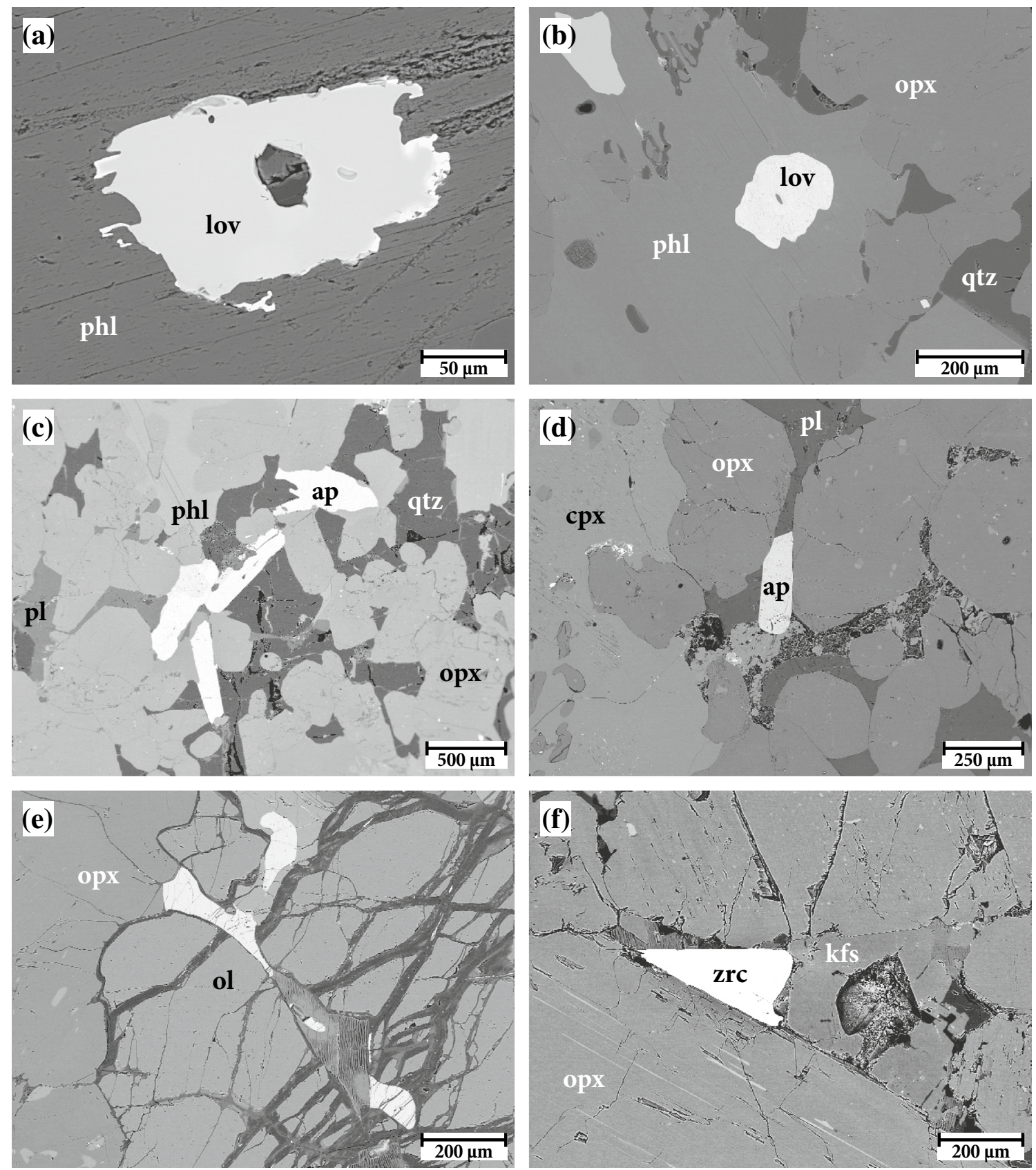

Fig. 12 Back-scatter electron images of accessory mineral phases in the analysed Lower Zone lithologies. a Subhedreal loveringite in phlogopite (NG2-180). b Subhedreal loveringite in association with interstitial phlogopite and quartz (NG2-762). c Euhedral prismatic apatite in association with quartz, phlogopite and minor plagioclase (NG2-762). d Euhedral prismatic apatite in association with relatively

after apatite crystallisation, possibly due to compaction. Genetic and temporal relationships may even be more complicated, as some of the equant apatite crystals coexist with irregular-shaped ones, which may be interpreted as resorbed relicts of early apatite generations that interacted

anorthite-rich plagioclase. Note the absence of quartz, phlogopite and other evolved minerals (NG2-737). e Partially resorbed apatite next to plagioclase (NG2-490). f Subhedreal interstitial zircon together with alkali feldspar (NG2-180). See text for further explanation. ol olivine, $o p x$ orthopyroxene, $c p x$ clinopyroxene, $p l$ plagioclase, qtz quartz, $p h l$ phlogopite, zrc zircon, ap apatite

with pulses of apatite-undersaturated interstitial melt that migrated through the crystal pile (Fig. 12e).

Loveringite is a rather unusual REE-rich oxide mineral with the chemical formula $(\mathrm{Ca}, \mathrm{Ce})(\mathrm{Ti}, \mathrm{Fe}, \mathrm{Cr}, \mathrm{Mg})_{21} \mathrm{O}_{38}$, belonging to the crichtonite group, and has been reported 
in a number of layered intrusions, e.g. Bushveld, Laouni and the Early Proterozoic Penikat, Koitelainen, Burakovsky and Last-Yavr (Cameron 1979; Alapieti and Lahtinen 1986; Lorand et al. 1987; Tarkian and Mutanen 1987; Barkov et al. 1994, 1996). Due to its enrichment in $\mathrm{Zr}$ and REE, Tarkian and Mutanen (1987) envisaged loveringite to have crystallised from a crustally contaminated mafic magma in the Koitelainen intrusion in northern Finland. In contrast, Lorand et al. (1987) proposed that loveringite in the Laouni Complex in Algeria crystallised from highly evolved liquids that migrated through the cumulus pile as a result of compaction, essentially following Irvine's (1980) seminal work on infiltration metasomatism.

The only reported occurrence of loveringite in the Bushveld Complex so far has been in the CZ by Cameron (1978b). In our LZ sample set, loveringite occurs in two of the three lowermost samples located close to the basal contact (melagabbronorite NG2-762, melanorite NG2-737), and in an orthopyroxenite sample in the upper third of the LZ (orthopyroxenite NG2-180). The presence of loveringite at the base of the intrusion may be consistent with local crustal contamination of the magma, as proposed by Tarkian and Mutanen (1987), based on a correlation between the occurrence of loveringite and crustal anatectic melts, but this does not hold for the sample further up in the sequence. Therefore, the main control on loveringite crystallisation seems to be the degree of interstitial melt fractionation, rather than crustal contamination, as loveringite is generally associated with the most fractionated mineral assemblage, not only in samples close to the base of the intrusion, but also higher up in the sequence (orthopyroxenite NG2180). A possible explanation for the occurrence of loveringite together with a nearly cotectic interstitial mineral mode at this stratigraphic level may be that the orthopyroxenite represents a sill, which has been emplaced relatively late, when permeability across most parts of the LZ was already low, thus hampering effective melt migration.

\section{Implications for layered intrusions}

Several studies have shown that isotopic disequilibrium between rock-forming cumulus and intercumulus minerals is a ubiquitous feature throughout the entire succession of the Bushveld Complex and other layered intrusions. Disequilibrium $\mathrm{Sr}$ isotope compositions between plagioclase and coexisting orthopyroxene have been shown for the $\mathrm{CZ}$ and lower MZ (Eales et al. 1990; Seabrook et al. 2005; Chutas et al. 2012; Roelofse and Ashwal 2012; Yang et al. 2013; Mangwegape et al. 2016). These results were further confirmed by Prevec et al. (2005), who measured Nd isotope compositions of the same two minerals in Merensky Reef samples. These findings are consistent with extensive multiphase melt migration, whereby cumulus minerals crystallised from a geochemically distinct magma in comparison to the intercumulus phases (Fig. 9a, b).

Moreover, $\mathrm{Pb}$ isotopic disequilibrium between plagioclase and sulphide has been reported for a number of CZ samples (Mathez and Waight 2003; Mathez and Kent 2007). Considering the results of our study, the observed isotopic disequilibrium may be explained by a post-cumulus migration event of a sulphur-saturated melt through the crystal pile, as the sulphide texture indicates previous sulphide collection rather than in situ sulphur saturation. Additionally, melt migration may represent a potential mechanism to introduce sulphide mineralisation elsewhere in the cumulus pile. Maier et al. (2008) and McDonald and Holwell (2011) suggested that the Platreef comprised a number of mineralised sills, which intruded as sulphidesaturated crystal mushes. Therefore, it is conceivable that these mushes did not only form discrete sills, but also interacted with the existing cumulate, which resulted in further migration of the liquid components of the mush, i.e. liquid sulphide and residual melt. Subsequently, these liquids crystallised in zones of low flow velocity, possibly similar to what can be observed in sample NG2-300 (Fig. 7).

Another important aspect of melt migration is its bearing on the origin and formation of datable minerals, such as zircon. In light of the evidence presented in our study, it is rather unlikely that zircon and baddeleyite crystallised from the same magma as that which produced the cumulus minerals. Instead, migration of compositionally diverse residual melts through the crystal pile, and associated mixing, seems to be a common feature in parts of the Bushveld Complex, and thus is further substantiated by common isotopic disequilibrium between cumulus and intercumulus minerals (Eales et al. 1990; Mathez and Waight 2003; Seabrook et al. 2005; Prevec et al. 2005; Mathez and Kent 2007; Chutas et al. 2012; Roelofse and Ashwal 2012; Yang et al. 2013; Mangwegape et al. 2016). As a consequence, interstitial zircon may have crystallised from any pulse of residual melt that migrated through the cumulus crystal framework, and potentially mixed with resident melt. Most importantly, calculations of trapped liquid estimates suggest that melt expulsion occurred at variable degrees of fractionation, which is why evolved residual melt may have been replaced with more primitive melt from elsewhere, thus delaying zircon saturation. Recent high-precision $\mathrm{U}-\mathrm{Pb}$ isotopic dating of zircon and baddeleyite from the $\mathrm{CZ}$ of the western Bushveld Complex has been used to argue that the complex comprises discrete sheet-like intrusions, which were not emplaced sequentially, but were intruded beneath older layers (Wall 2016; Mungall et al. 2016). Our study, however, prompts the question as to what interstitial zircon records: the actual timing of emplacement of a layer or merely the crystallisation of zircon from a later, separate and 
unrelated episode of residual melt that migrated through the cumulate.

This problem has been discussed by Zeh et al. (2015) and can be particularly well demonstrated in the Upper CZ of the Bushveld Complex, for which recent high-precision geochronology suggested that the Merensky Reef was at least 2 million years younger than the overlying Bastard Reef (Wall 2016). However, field evidence from the western Bushveld clearly shows the opposite: the Bastard Reef cross-cuts the Merensky Reef (De Klerk 1982; Carr et al. 1994). Hence, this salient inconsistency highlights that precise $\mathrm{U}-\mathrm{Pb}$ zircon ages may not record the actual timing of emplacement of the reefs, but may represent a later phase of residual melt migration from elsewhere in the crystal pile. A possible explanation for the Merensky paradox, relating to the inconsistency of field evidence and zircon age dating, may be that the Merensky pyroxenite, with its pegmatoidal texture, remained permeable for a longer time than the Bastard pyroxenite.

Ultimately, this study demonstrates the importance of large-scale elemental mapping for an objective assessment of the compositional variation exhibited by the interstitial minerals. Therefore, a limited number of point analyses on interstitial phases may not always record the full range in chemical variability; this may explain the erratic trend in anorthite contents across the LZ (Fig. 4).

\section{Summary}

The Lower Zone of the Bushveld is a highly variable succession of ultramafic lithologies, with minor mafic intervals. Igneous layering is generally complex, showing sharp contacts between pyroxenite and peridotite, although gradual transitions may also be present. The lateral continuity of individual layers is limited, as they commonly taper off over short distances. Together with the lack of fractionation in $\mathrm{Mg} \#$ of orthopyroxene, variable whole rock as well as in situ $\mathrm{Sr}$ isotope compositions and erratic $\mathrm{Pt} / \mathrm{Pd}$ ratios, these observations strongly suggest an emplacement of the Lower Zone as a sill complex rather than its crystallisation from a large magma chamber. The presence of a relatively thin sulphide-bearing interval of noritic composition provides further support for a sill-like origin of the zone.

Our detailed mineralogical and microtextural study shows that most samples from the Lower Zone show little evidence for a truly trapped liquid component in the cumulates. Melt migration may be a commonly occurring process in cumulate rocks, as indicated by the non-cotectic proportions of evolved mineral phases, such as quartz, phlogopite and alkali feldspar in most samples.

This has important implications for the formation of the Lower Zone and by extension for layered intrusions in general: (1) interstitial sulphide mineralisation may be introduced into a cumulate via migrating melts; (2) most importantly, late stage minerals, such as zircon, rarely crystallise from truly trapped liquid. Therefore, dating of interstitial zircon from cumulates is unlikely to record the actual timing of emplacement, but merely the crystallisation of a later unrelated episode of residual melt migrating through the cumulate.

Acknowledgements We thank Anthony Oldroyd and Duncan Muir for their help with sample preparation and analytical work. The manuscript benefited from constructive reviews by three anonymous reviewers. We also thank Timothy Grove for editorial handling.

Open Access This article is distributed under the terms of the Creative Commons Attribution 4.0 International License (http://creativecommons.org/licenses/by/4.0/), which permits unrestricted use, distribution, and reproduction in any medium, provided you give appropriate credit to the original author(s) and the source, provide a link to the Creative Commons license, and indicate if changes were made.

\section{References}

Alapieti TT, Lahtinen JJ (1986) Stratigraphy, petrology, and platinumgroup element mineralization of the early Proterozoic Penikat layered intrusion, northern Finland. Econ Geol 81:1126-1136

Ashwal LD, Webb SJ, Knoper MW (2005) Magmatic stratigraphy in the Bushveld Northern Lobe: continuous geophysical and mineralogical data from the $2950 \mathrm{~m}$ Bellevue drillcore. S Afr J Geol 108:199-232

Barkov AY, Pakhomovskii YA, Trofimov NN, Lavrov MM (1994) Loveringite: a first occurrence in Russia from the Burakovsky layered intrusion, Karelia. Neues Jahrbuch für Mineralogie H3:101-111

Barkov AY, Saychenko YE, Men'shikov YP, Barkova LP (1996) Loveringite from the Last-Yavr mafic-ultramafic intrusion, Kola Peninsula; a second occurrence in Russia. Nor Geol Tidsskr $76: 115-120$

Barnes SJ (1986) The effect of trapped liquid crystallization on cumulus mineral compositions in layered intrusions. Contrib Mineral Petrol 93:524-531

Barnes S-J, Maier WD, Curl EA (2010) Composition of the marginal rocks and sills of the Rustenburg Layered Suite, Bushveld Complex, South Africa: implications for the formation of the platinum-group element deposits. Econ Geol 105:1491-1511

Bédard JH, Kerr RC, Hallworth MA (1992) Porous sidewall and sloping floor crystallization experiments using a reactive mush: implications for the self-channelization of residual melts in cumulates. Earth Planet Sci Lett 111:319-329

Boorman S, Boudreau A, Kruger FJ (2004) The Lower Zone-Critical Zone transition of the Bushveld Complex: a quantitative textural study. J Petrol 45:1209-1235

Boudreau AE (1999) PELE - a version of the MELTS software program for the PC platform. Comput Geosci 25:201-203

Cameron EN (1978a) The Lower Zone of the Eastern Bushveld Complex in the Olifants River Trough. J Petrol 19:437-462

Cameron EN (1978b) An unusual titanium-rich oxide mineral from the Eastern Bushveld Complex. Am Mineral 63:37-39

Cameron EN (1979) Titanium-bearing oxide minerals of the critical zone of the Eastern Bushveld Complex. Am Mineral 64:140-150 
Carr HW, Groves DI, Cawthorn RG (1994) The importance of synmagmatic deformation in the formation of Merensky Reef potholes in the Bushveld Complex. Econ Geol 89:1398-1410

Cawthorn RG (2015) The Bushveld Complex, South Africa. In: Charlier B, Namur O, Latypov R, Tegner C (eds) Layered intrusions. Springer, Dordrecht, pp 517-587

Chutas NI, Bates E, Prevec SA et al (2012) Sr and Pb isotopic disequilibrium between coexisting plagioclase and orthopyroxene in the Bushveld Complex, South Africa: microdrilling and progressive leaching evidence for sub-liquidus contamination within a crystal mush. Contrib Mineral Petrol 163:653-668

De Klerk WJ (1982) The geology, geochemistry and silicate mineralogy of the Upper Critical Zone of the North-western Bushveld Complex, at Rustenburg Platinum Mines, Union section. MSc thesis, Rhodes University

Eales HV, Cawthorn RG (1996) The Bushveld Complex. In: Cawthorn RG (ed) Developments in petrology. Elsevier, Amsterdam, pp 181-229

Eales HV, De Klerk WJ, Teigler B (1990) Evidence for magma mixing processes within the Critical and Lower Zones of the northwestern Bushveld Complex, South Africa. Chem Geol $88: 261-278$

Engelbrecht JP (1985) The chromites of the Bushveld Complex in the Nietverdiend area. Econ Geol 80:896-910

Gatehouse BM, Grey IE, Campbell IH, Kelly P (1978) The crystal structure of loveringite-a new member of the crichtonite group. Am Mineral 63:28-36

Godel B, Barnes S-J, Maier WD (2011) Parental magma composition inferred from trace element in cumulus and intercumulus silicate minerals: an example from the Lower and Lower Critical Zones of the Bushveld Complex, South-Africa. Lithos 125:537-552

Hall AL (1932) The Bushveld Igneous Complex of the central Transvaal. Mem Geol Surv S Afr 28:530

Hulbert LJ (1983) A petrological investigation of the Rustenburg Layered Suite and associated mineralization south of Potgietersrus. $\mathrm{PhD}$ thesis, University of Pretoria

Irvine TN (1980) Magmatic infiltration metasomatism, double-diffusive fractional crystallization, and adcumulus growth in the Muskox intrusion and other layered intrusions. In: Hargraves RB (ed) Physics of magmatic processes. Princeton University Press, Princeton, NJ, pp 325-383

Jerram DA, Cheadle MJ, Philpotts AR (2003) Quantifying the building blocks of igneous rocks: are clustered crystal frameworks the foundation? J Petrol 44:2033-2051

Karykowski BT, Polito PA, Maier WD et al (2017) New insights into the petrogenesis of the Jameson Range layered intrusion and associated Fe-Ti-P-V-PGE-Au mineralisation, West Musgrave Province, Western Australia. Miner Deposita 52:233-255

Lee CA, Tredoux M (1986) Platinum-group element abundances in the Lower and the Lower Critical Zones of the eastern Bushveld Complex. Econ Geol 81:1087-1095

Lorand JP, Cottin J-Y, Parodi GC (1987) Occurrence and petrological significance of loveringite in the Western Laouni layered complex, southern Hoggar, Algeria. Can Miner 25:683-693

Maier WD, Arndt NT, Curl EA (2000) Progressive crustal contamination of the Bushveld Complex: evidence from $\mathrm{Nd}$ isotopic analyses of the cumulate rocks. Contrib Mineral Petrol 140(3):316-327

Maier WD, de Klerk L, Blaine J et al (2008) Petrogenesis of contact-style PGE mineralization in the northern lobe of the Bushveld Complex: comparison of data from the farms Rooipoort, Townlands, Drenthe and Nonnenwerth. Miner Deposita 43:255-280

Maier WD, Barnes S-J, Groves DI (2013) The Bushveld Complex, South Africa: formation of platinum-palladium, chrome- and vanadium-rich layers via hydrodynamic sorting of a mobilized cumulate slurry in a large, relatively slowly cooling, subsiding magma chamber. Miner Deposita 48:1-56

Maier WD, Barnes S-J, Karykowski BT (2016a) A chilled margin of komatiite and Mg-rich basaltic andesite in the western Bushveld Complex, South Africa. Contrib Mineral Petrol 171:57

Maier WD, Karykowski BT, Yang S (2016b) Formation of transgressive anorthosite seams in the Bushveld Complex via tectonically induced mobilisation of plagioclase-rich crystal mushes. Geosci Front 7(6):875-889

Mangwegape M, Roelofse F, Mock T, Carlson RW (2016) The Srisotopic stratigraphy of the Northern Limb of the Bushveld Complex, South Africa. J Afr Earth Sci 113:95-100

Mathez EA, Kent AJR (2007) Variable initial Pb isotopic compositions of rocks associated with the UG2 chromitite, eastern Bushveld Complex. Geochim Cosmochim Acta 71:5514-5527

Mathez EA, Waight TE (2003) Lead isotopic disequilibrium between sulfide and plagioclase in the bushveld complex and the chemical evolution of large layered intrusions. Geochim Cosmochim Acta 67:1875-1888

McDonald I, Holwell DA (2011) Geology of the Northern Bushveld Complex and the setting and genesis of the Platreef Ni-Cu-PGE deposit. Rev Econ Geol 17:297-327

McDonough WF, Sun S-s (1995) The composition of the Earth. Chem Geol 120:223-253

Meurer WP, Boudreau AE (1996) Compaction of density-stratified cumulates: effect on trapped-liquid distribution. J Geol 104:115-120

Meurer WP, Meurer MES (2006) Using apatite to dispel the "trapped liquid" concept and to understand the loss of interstitial liquid by compaction in mafic cumulates: an example from the Stillwater Complex, Montana. Contrib Mineral Petrol 151:187-201

Mungall JE, Kamo SL, McQuade S (2016) U-Pb geochronology documents out-of-sequence emplacement of ultramafic layers in the Bushveld Igneous Complex of South Africa. Nat Commun $7: 13385$

Naslund HR, McBirney AR (1996) Mechanisms of formation of igneous layering. Dev Petrol 15:1-43

Nicholson DM, Mathez EA (1991) Petrogenesis of the Merensky Reef in the Rustenburg section of the Bushveld Complex. Contrib Mineral Petrol 107:293-309

Piccoli PM, Candela PA (2002) Apatite in Igneous Systems. Rev Mineral Geochem 48:255-292

Prevec SA, Ashwal LD, Mkaza MS (2005) Mineral disequilibrium in the Merensky Reef, western Bushveld Complex, South Africa: new Sm-Nd isotopic evidence. Contrib Mineral Petrol 149:306-315

Roelofse F, Ashwal LD (2012) The lower Main Zone in the northern limb of the Bushveld Complex-a $>1.3 \mathrm{~km}$ thick sequence of intruded and variably contaminated crystal mushes. J Petrol 53:1449-1476

Scoates JS, Wall CJ (2015) Geochronology of layered intrusions. In: Charlier B, Namur O, Latypov R, Tegner C (eds) Layered intrusions. Springer, Dordrecht, pp 3-74

Scoon RN, Teigler B (1995) A new LG-6 chromite reserve at Eerste Geluk in the boundary zone between the central and southern sectors of the eastern Bushveld Complex. Econ Geol 90:969-982

Seabrook CL, Cawthorn RG, Kruger FJ (2005) The Merensky Reef, Bushveld Complex: mixing of minerals not mixing of magmas. Econ Geol 100:1191-1206

Sharpe MR (1981) The chronology of magma influxes to the eastern compartment of the Bushveld Complex as exemplified by its marginal border groups. J Geol Soc 138:307-326

Tait S, Jaupart C (1992) Compositional convection in a reactive crystalline mush and melt differentiation. J Geophys Res Solid Earth 97:6735-6756 
Tarkian M, Mutanen T (1987) Loveringite from the Koitelainen layered intrusion, northern Finland. Mineral Petrol 37:37-50

Tegner C, Cawthorn RG, Kruger FJ (2006) Cyclicity in the Main and Upper Zones of the Bushveld Complex, South Africa: crystallization from a zoned magma sheet. J Petrol 47:2257-2279

Teigler B (1990) Mineralogy, petrology and geochemistry of the Lower and Lower Critical Zones, northwestern Bushveld Complex. $\mathrm{PhD}$ thesis, Rhodes University

Teigler B, Eales HV (1996) The Lower and Critical Zones of the western limb of the Bushveld Complex as intersected by the Nooitgedacht boreholes. Bull Geol Surv S Afr 111, $126 \mathrm{p}$

Tollari N, Baker DR, Barnes S-J (2008) Experimental effects of pressure and fluorine on apatite saturation in mafic magmas, with reference to layered intrusions and massif anorthosites. Contrib Mineral Petrol 156:161-175

Wager LR (1960) The major element variation of the layered series of the Skaergaard intrusion and a re-estimation of the average composition of the hidden layered series and of the successive residual magmas. J Petrol 1:364-398

Wall CJ (2016) Establishing the age and duration of magmatism in large open-system layered intrusions from the high-precision geochronology of the Neoarchean Stillwater Complex and
Paleoproterozoic Bushveld Complex. PhD thesis, University of British Columbia

Webster JD, Piccoli PM (2015) Magmatic apatite: a powerful, yet deceptive. Mineral Elem 11:177-182

Wilson AH (2012) A chill sequence to the Bushveld Complex: insight into the first stage of emplacement and implications for the parental magmas. J Petrol 53:1123-1168

Wilson AH (2015) The earliest stages of emplacement of the Eastern Bushveld Complex: development of the Lower Zone, Marginal Zone and Basal Ultramafic Sequence. J Petrol 56:347-388

Yang S-H, Maier WD, Lahaye Y, O’Brien H (2013) Strontium isotope disequilibrium of plagioclase in the Upper Critical Zone of the Bushveld Complex: evidence for mixing of crystal slurries. Contrib Mineral Petrol 166:959-974

Yudovskaya MA, Kinnaird JA, Sobolev AV et al (2013) Petrogenesis of the Lower Zone olivine-rich cumulates beneath the Platreef and their correlation with recognized occurrences in the Bushveld Complex. Econ Geol 108:1923-1952

Zeh A, Ovtcharova M, Wilson AH, Schaltegger U (2015) The Bushveld Complex was emplaced and cooled in less than one million years-results of zirconology, and geotectonic implications. Earth Planet Sci Lett 418:103-114 